\title{
correspondence
}

\section{Nitrates and nitrites cannot be eliminated}

SiR,-The report that nitrite has induced cancer in animals is not surprising as it has long been known to be mutagenic. The benefits from the use of nitrite as a food additive may outweight the hazards that it presents as a mutagen and carcinogen. The amounts of nitrite in food either 'naturally' or as additives should obviously be kept to the minimum effective levels. Small amounts of nitrites and nitrates are formed by the electric discharge of lighting and it is difficult to avoid this contaminating drinking water.

Nitrate is, however, formed by the decomposition of organic matter and indeed the nitrate used for gunpowder was made in this way until the deposits of Chilean saltpetre became available in the nineteenth century. In conditions of poor sanitation the nitrate formed by

"decomposition of organic matter"

including faecal residues will be a

pollutant. In dry regions this is likely to be present in air as a fine powder and in moist areas as a water contaminant. Improvement in hygiene could therefore remove or reduce a carcinogenic hazard.

Nitrite is, however, formed in the intestine by bacterial action (Tannenbaum, S. R. Fett, D., Young, V. R., Land, P. D. \& Bruce, W. R. Science 200, 1487; 1978) and it is difficult to see how this could be prevented.

Nitrates are converted to nitrites in the body. Nitrites could be carcinogenic directly by reacting with the purine residues of nucleic acid. They can also act by reaction with secondary or tertiary amines to form nitrosamines which may be metabolised by tissue enzyme to alkylating agents.

The new findings increase the correlation between mutagenicity and carcinogenicity and indicate that exposure to nitrates and nitrites should be reduced although they cannot be completely removed. Yours faithfully, E. Boyland

The London School of Hygiene and Tropical Medicine

\section{Foxing fungus}

SIR,-The interesting letter from Maynell and Newsam (3 August, page 466), confirming the suggestion that foxed paper has suffered from fungal attack, raises the question "Why was this form of deterioration called foxing?" The

dictionary explanation is that the word refers to the brownish colour. If that were all, rusting would have been a more suitable word. I have often wondered whether it is merely a coincidence that several harmful effects, now known to be caused by fungal growth, are verbally related to the fox. For example : fox-evil, now called alopecia from the Greck for a fox; wine fermented by a contaminated yeast culture; and beer that has 'gone off'.

Robert Graves argued somewhere that fox in the Bible is often a mistranslation of mushroom. For example: "Take us the foxes, the little foxes, that spoil the vines" (Song of Solomon 2 $15)$. He explained the extraordinary story (Judges 15 4,5) of Samson tying firebrands to the tails of pairs of foxes, and sending them off to burn the Philistine's crops, thus: "he inflamed his soldiers by feeding them on mushrooms (? Amanita muscaria) and sent them in pairs to destroy the crops".

I wonder whether there could have been a similar confusion in other languages. The metaphorical use of fox to describe colour or cunning is understandable. The uses of the word that are discusse here predate recognition of the fungal category. Nevertheless, they all have some connection with observable growth. We get fox from a Teuton rather than a Latin root. Could there have been a confusion between the German wuchs and fuchs. In English, the $\mathrm{f}$ becomes a $\mathrm{v}$ in vixen. It would be interesting to know whether any scholarly person has thought about the matter. It's not my subject. Yours faithfully,

Harpenden, UK N. W. PIRIE

\section{Compulsory boycott}

SiR,-Unlike many other people, I never intended to boycott the Fourteenth International Congress of Genetics of Moscow, August 1978. I was very anxious to meet our Russian colleagues. Five communications from members of my department were accepted by the conference organising committee. Two of their authors had even been invited to act as co-chairman for some of the congress sessions.

But the Soviet authorities refused to grant me an entry visa, without giving any motive. To show their solidarity, my collaborators decided to cancel their participation in the congress.

In answer to my protestations made by telegram, I received (on 18 and 19 August) two calls from the organising committee, assuring me that there had been a technical mistake which would be rectified promptly. I was asked to wait for further information. I was still waiting, when the congress was almost at an end

Who has boycotted the congress? Not I!

But will my Russian friends hear of it? Yours faithfully,

Namur, Belgium

Antoine Elens

\section{Making mincemeat of our common language}

SiR.-An American visiting Britain, and wishing to cook a hamburger (whatever its load of carcinogens) is in for a rastronomic surprise if he acts on the information given by my friend Tom Jukes
(27 July, page 307). If, in an attempt to purchase ground beef he asks for mincemeat, he will receive "a mixture of currants, raisins, sugar, suet etc." (see the Oxford Dictionary), the stuff we British use at Christmas to make the traditional mince pies. If he is lucky, there may even be some brandy in the mincemeat; a hundred years ago our more virile ancestors included steak, but fruit and sweet substances always predominated.

The English synonym for ground beef is simply mince. The shopkeeper would understand what was needed if asked for minced beef.

$$
\text { Yours faithfully, }
$$

KenNeth MellanBy

Monks Wood Experimental Station. Abbots Ripton, Huntingdon.

\section{Marsh mallow grows in Britain}

SrR,-Rosemary Angel, in her review (4 May page 79) of Major Medicinal Plants: Botany, Culture, and Uses, takes the author, Julia F. Morton, to task for saying that marsh mallow is grown in gardens in Great Britain. "No, I am afraid it is not," she says. Without wishing to be picayune, I feel I should say that it is. I have grown marsh mallow in two successive gardens, and it is one of the most beautiful plants I know. It is growing in my garden now. And I am well aware of the difference between common mallow, musk mallow, marsh mallow, and the others. Yours faithfully, Robert K. G. Temple

Bridgwater, Somerset, UK

\section{Sex and cancer}

SIR,-In his review of A. C. Braun's book, The Story of Cancer: On its Nature, Causes and Control, Richard Peto says, ". . . many, and perhaps most, cancers are caused by certain sexual habits, smoking habits, and gross aspects of diet rather than by contaminants."

For God's sake, Peto, which habits? Are thousands, perhaps millions of human beings to perish through your reticence (or bashfulness)?

And if - as can hardly be doubtedthe Regius Professor is correct, can he tell us which sexual habits of plants cause their cancers? Or which smoking habits?

Yours in fear and trembling,

Los Angeles, CA, USA 